\title{
The effect of mild induced hypothermia on outcomes of patients after cardiac arrest: a systematic review and meta-analysis of randomised controlled trials
}

\author{
Xi Wen Zhang ${ }^{\dagger}$, Jian Feng Xie ${ }^{\dagger}$, Jian Xiao Chen, Ying Zi Huang, Feng Mei Guo, Yi Yang and Hai Bo Qiu*
}

\begin{abstract}
Introduction: Mild induced hypothermia $(\mathrm{MIH})$ is believed to reduce mortality and neurological impairment after out-of-hospital cardiac arrest. However, a recently published trial demonstrated that hypothermia at $33^{\circ} \mathrm{C}$ did not confer a benefit compared with that of $36^{\circ} \mathrm{C}$. Thus, a systematic review and meta-analysis of randomised controlled trials (RCTs) was made to investigate the impact of $\mathrm{MIH}$ compared to controls on the outcomes of adult patients after cardiac arrest.

Methods: We searched the following electronic databases: PubMed/MEDLINE, the Cochrane Library, Embase, the Web of Science, and Elsevier Science (inception to December 2014). RCTs that compared MIH with controls with temperature $>34^{\circ} \mathrm{C}$ in adult patients after cardiac arrest were retrieved. Two investigators independently selected RCTs and completed an assessment of the quality of the studies. Data were analysed by the methods recommended by the Cochrane Collaboration. Random errors were evaluated with trial sequential analysis.

Results: Six RCTs, including one abstract, were included. The meta-analysis of included trials revealed that MIH did not significantly decrease the mortality at hospital discharge (risk ratio $(R R)=0.92 ; 95 \%$ confidence interval $(\mathrm{Cl})$, $0.82-1.04 ; p=0.17$ ) or at 6 months or 180 days ( $R R=0.94 ; 95 \% \mathrm{Cl}, 0.73-1.21 ; p=0.64)$, but it did reduce the mortality of patients with shockable rhythms at hospital discharge $(\mathrm{RR}=0.74 ; 95 \% \mathrm{Cl}, 0.59-0.92 ; p=0.008)$ and at 6 months or 180 days. However, MIH can improve the outcome of neurological function at hospital discharge $(\mathrm{RR}=0.80 ; 95 \% \mathrm{Cl}, 0.64-0.98 ; p=0.04)$ especially in those patients with shockable rhythm but not at 6 months or 180 days. Moreover, the incidence of complications in the $\mathrm{MIH}$ group was significantly higher than that in the control group. Finally, trial sequential analysis indicated lack of firm evidence for a beneficial effect.

Conclusion: The available RCTs suggest that MIH does not appear to improve the mortality of patients with cardiac arrest while it may have a beneficial effect for patients with shockable rhythms. Although MIH may result in some adverse events, it helped lead to better outcomes regarding neurological function at hospital discharge. Large-scale ongoing trials may provide data better applicable to clinical practice.
\end{abstract}

\footnotetext{
* Correspondence: haiboq2000@163.com

${ }^{\dagger}$ Equal contributors

Department of Critical Care Medicine, Zhongda Hospital, School of Medicine

Southeast University, No.87, Dingjiaqiao Road, Gulou District, Nanjing 210009,

China
} 


\section{Introduction}

Millions of people suffer sudden cardiac arrest (CA) every year in the whole world, often related to coronary heart disease. The global incidence of out-of-hospital cardiac arrest (OHCA) is about 82.9 per 100,000 population within all age groups, and 213.1 per 100,000 population in adult groups [1]. Return of spontaneous circulation (ROSC) is achieved in $25 \%$ to $40 \%$ of the patients [2, 3]. However, the mortality and risk of neurological impairment is high. Global brain ischemia and the reperfusion injury following resuscitation may lead to brain tissue degeneration and loss of neurological function [4].

The 2010 guidelines of the American Heart Association recommend mild induced hypothermia $\left(\mathrm{MIH} ; 32-34{ }^{\circ} \mathrm{C}\right)$ as an important part of resuscitation for patients who have experienced CA [5]. Two randomised controlled trials (RCTs) have shown the beneficial effects of MIH in the improvement of survival and neurological outcomes of patients following CA [6, 7]. In addition, it has been shown in rats that hypothermia protects brain regions that display rapid as well as delayed neuronal damage and that a minimal time of hypothermia is necessary for effective neuronal protection [8]. However, MIH also interferes with numerous physiological and pathological processes and might induce unfavourable effects, such as cardiac dysrhythmia and coagulopathy [7, 9]. Recently, many scholars have questioned the temperature and the efficacy of $\mathrm{MIH}$ and have criticised previous trials that showed that MIH improved the mortality of patients with OHCA because they had high risks of bias [10]. Nielsen and colleagues have shown that in unconscious survivors of OHCA of presumed cardiac origin, hypothermia at a targeted temperature of $33^{\circ} \mathrm{C}$ did not confer a benefit compared with a targeted temperature management of $36{ }^{\circ} \mathrm{C}$ [11]. Although MIH has been implemented as the standard care for patients after CA in many countries, the evidence for its possible beneficial effects are still controversial. Thus, the object of this systematic review and meta-analysis was to evaluate the impact of MIH compared to controls with temperature $>34{ }^{\circ} \mathrm{C}$ in adult patients after $\mathrm{CA}$ on mortality and neurologic performance as main outcomes.

\section{Methods}

\section{Eligibility criteria}

We included trials with the following features:

1) Type of study: Randomised controlled clinical trials

2) Population: Adult patients (aged more than 18 years) who suffered from CA (regardless whether in-hospital CA (IHCA) or OHCA) and who were successfully resuscitated

3) Intervention: MIH (any body target temperature $\leq 34{ }^{\circ} \mathrm{C}$ )
4) Control (treatment according to the standard treatment after $\mathrm{CA}$ in any body temperature $>34{ }^{\circ} \mathrm{C}$ with or without temperature intervention)

5) The following outcomes were included. a) Primary outcomes: mortality at hospital discharge, mortality at 6 months or 180 days and long-term (more than 1 year); b) secondary outcomes: neurological function during hospital stay and 6 months or 180 days in cerebral performance categories (CPC) and adverse events.

\section{Search strategy for the identification of studies}

We conducted a search of the following databases until December 2014: Medline, Embase, Cochrane (Central) database, Elsevier, Web of Science and ClinicalTrials.gov (inception to December 2014). Searches were conducted as described by Nielsen et al. [10] and Arrich et al. [12] (see Additional file 1: Tables S1 and S2). There was no language restriction.

\section{Study selection}

Two reviewers independently screened titles and abstracts to determine whether a particular study met the inclusion criteria. The full texts of the articles were then reviewed independently according to the inclusion and exclusion criteria. Any discrepancies were resolved by a consensus on the inclusion or exclusion of a particular study after a discussion with a third reviewer.

\section{Data extraction and management}

Two reviewers independently extracted data using a standardised data extraction protocol. Any disagreements between the two reviewers were resolved by a discussion, whereby a consensus was then reached. The relevant outcomes were mortality, neurological function and adverse events potentially related to MIH. Neurological function was evaluated according to $\mathrm{CPC}$, where a CPC score of 1 and 2 was defined as a good neurological outcome and a score of 3-5 was defined as a poor neurological outcome. We further defined outcome at discharge as short-term outcome and outcome at 6 months as long-term outcome.

\section{Methodological risk of bias assessment}

We summarised the evidence applying GRADE levels [13] (high, moderate, low, and very low) by evaluating design, quality, consistency, precision, directness and possible publication bias of the included trials using GRADEpro Guideline Development Tool.

We assessed random sequence generation, allocation concealment, blinding of participants and personnel, blinding of outcome assessment, incomplete outcome data and selective reporting to assess the internal validity 
of the identified trials according to the Cochrane Handbook [14].

Sensitivity analyses were used to assess the impact of study quality issues on the overall effect estimate and the effect size of all identified trials when neglecting heterogeneity and publication status conducted by STATA 11.0 (Stata Corporation, College Station, TX, USA).

\section{Subgroup meta-analysis}

A subgroup meta-analysis was performed to determine the effect of the initial rhythms (shockable and nonshockable rhythms) on the efficiency of MIH with regard to the outcomes of patients with CA. The articles without specific classification of initial rhythms were classified into shockable and non-shockable rhythm groups.

In all included studies, we also performed metaanalysis to compare the effects between MIH and no target temperature (any body temperature $>34{ }^{\circ} \mathrm{C}$ without cooling or warming methods) on the outcomes of adult patients after CA. Moreover, meta-analysis of the effects between $\mathrm{MIH}$ and target temperature management (TTM; any body temperature $>34{ }^{\circ} \mathrm{C}$ with cooling or warming methods) on the outcomes of adult patients after CA was also performed.

\section{Statistical analysis}

The meta-analysis of the effect of MIH on outcomes in patients with CA was conducted using the methods recommended by the Cochrane Collaboration software RevMan 5.3 (The Nordic Cochrane Centre, Rigshospitalet, Copenhagen, Denmark). The statistical heterogeneity and inconsistency were measured and quantified by the Mantel-Haenszel $(\mathrm{M}-\mathrm{H})$ chi-square test and the $\mathrm{I}^{2}$ test in RevMan 5.3 [15]. The statistically significant heterogeneity was predefined as $p<0.10$ with the $\mathrm{M}-\mathrm{H}$ chisquare test. In addition, $\mathrm{I}^{2}$ index was used to assess heterogeneity in the meta-analysis. Higgins and colleagues proposed $25 \%, 50 \%$ and $75 \%$ of $\mathrm{I}^{2}$ values would mean low, medium and high heterogeneity, respectively [15]. In cases of obvious heterogeneity (i.e., $p<0.10$ with $\mathrm{M}-\mathrm{H}$ test; $\mathrm{I}^{2}>50 \%$ ), the meta-analysis employed the random-effects model; otherwise, the meta-analysis used the fixed-effects model. We reported a risk ratio (RR) with $95 \%$ confidence interval (CI) for the dichotomous data and weighted mean differences with $95 \%$ CIs for the continuous data. The publication bias was evaluated by visual inspection of the funnel plot.

Due to type I errors which result from an increased risk of random error and repeated significance testing $[16,17]$, we used trial sequential analysis (TSA; TSA software version 0.9 Beta; Copenhagen Trial Unit, Copenhagen, Denmark), which combines information size estimation with an adjusted threshold for statistical significance in the cumulative meta-analysis [16-18].
Information size was calculated as diversity-adjusted information size (DIS) [19], suggested by the relative risk reduction (RRR) of the intervention in the included trials.

\section{Results}

Summary of the studies

The flow diagram that shows the identification of studies throughout the review is illustrated in Fig. 1. Overall, we identified 4699 papers and excluded 4645 after screening the titles and abstracts for the terms "hypothermia", "cardiac arrest" and "randomised control trial". We retrieved 54 articles that were full-length manuscripts and, finally, six were included in this meta-analysis.

These six trials included 1417 patients. The subjects who were included were adult patients with CA who were randomised to $\mathrm{MIH}$ of $32-34{ }^{\circ} \mathrm{C}$ versus control intervention. A total of 730 subjects received hypothermia therapy while the remainder were in the control group. The methods of hypothermia therapy included external cooling, the use of an intravascular cooling device and continuous renal replacement therapy (CRRT). One study did not report the method of cooling [20]. Among all the included studies, three studies followed the patients for 6 months [7, 11, 21], and the others followed the patients for 14 days [22], 1 month [20] or until hospital discharge [6]. The main characteristics of the included studies are shown in Table 1.

\section{Random errors}

TSA was calculated with $\alpha=0.05$ and $\beta=0.20$ (power $80 \%)$ and a required diversity-adjusted information size based on the intervention effect suggested by the included trials using a fixed-effects model (RRR of $5.8 \%$ regarding mortality and 16,287 patients) and a randomeffects model (RRR of $7.29 \%$ regarding poor neurological function and 15,568 patients). TSA indicated lack of reliable and conclusive evidence for a beneficial effect of MIH for both mortality (Fig. 2a) and a poor neurological outcome (Fig. 2b), since the monitoring boundaries were not finally surpassed and the required information size was not reached.

\section{Impact on mortality}

Among the included studies, five studies of 1363 patients reported the mortality at hospital discharge and were included in the primary analysis. We detected no evidence of a publication bias after a funnel plot analysis (Additional file 2: Figure S1a). There was statistically insignificant heterogeneity $(p=0.24)$ and medium heterogeneity $\left(\mathrm{I}^{2}=28 \%\right)$ among all mortality at discharge analyses (Fig. 3a). The mortality rate was not significantly different between the MIH group and the control 


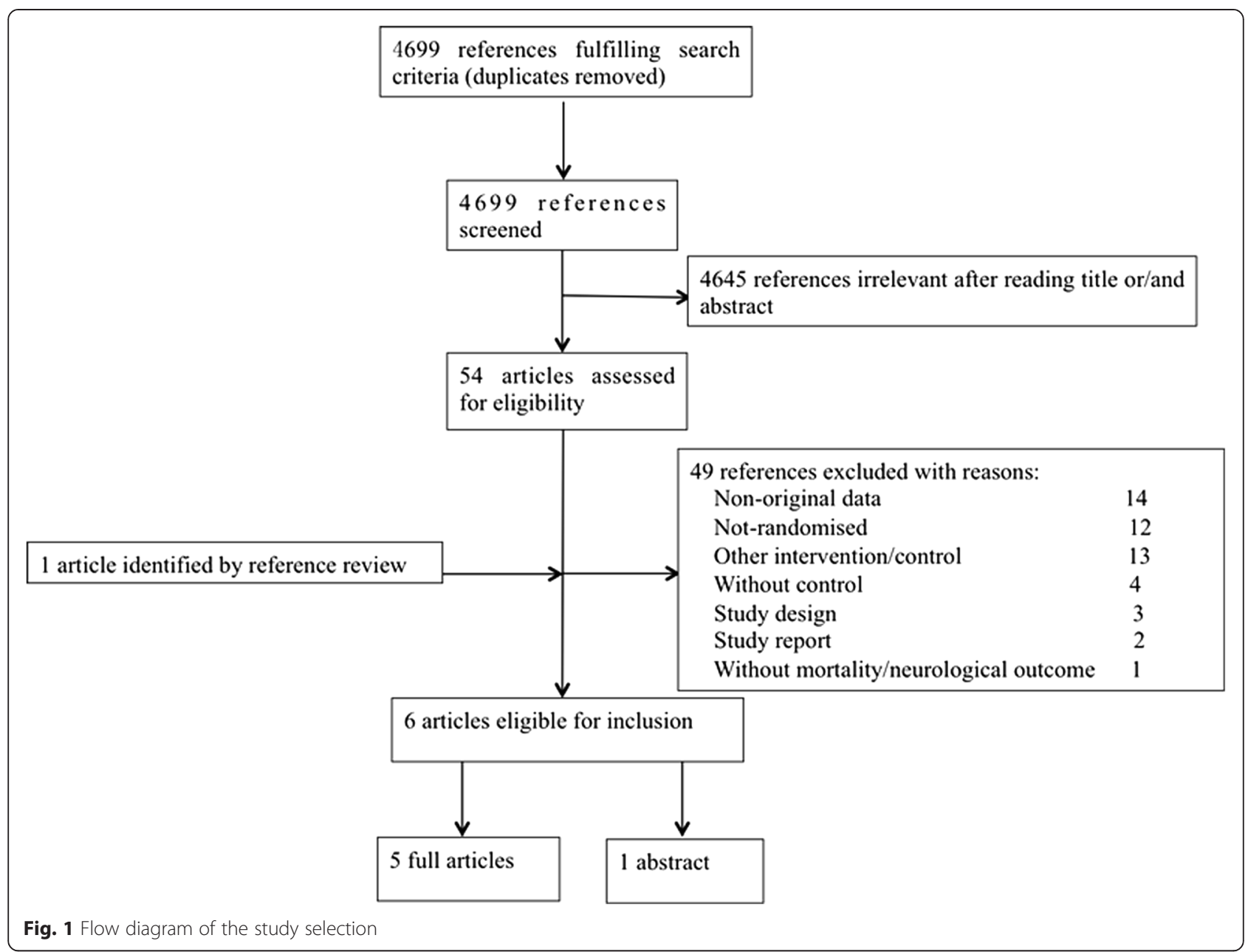

group $(\mathrm{RR}=0.92 ; 95 \% \mathrm{CI}, 0.82-1.04 ; p=0.17)$. However, a subgroup analysis showed that MIH could reduce the mortality of patients who had shockable rhythms and cardiac arrest $(\mathrm{n}=352 ; \mathrm{RR}=0.74 ; 95 \% \mathrm{CI}, 0.59-0.92$; $p=0.008)$. The RR of mortality for patients with nonshockable rhythms who received $\mathrm{MIH}$ versus those who did not (control group) was $0.87 \quad(\mathrm{n}=30 ; 95 \%$ CI, 0.66-1.15; $p=0.34)$.

Among the included studies, only three studies of 1256 patients reported the mortality at 6 months or 180 days. We detected no evidence of a publication bias after a funnel plot analysis (Additional file 2: Figure $\mathrm{S} 1 \mathrm{~b})$, but there was significant heterogeneity $(p=0.06)$ and substantial heterogeneity $\left(\mathrm{I}^{2}=65 \%\right)$ among the trials (Fig. 3b). Mortality at 6 months or 180 days was not reduced in patients treated with $\mathrm{MIH}$ compared to control $(\mathrm{RR}=0.94 ; 95 \% \mathrm{CI}, 0.73-1.21 ; p=0.64)$. However, a subgroup analysis showed that MIH could reduce the mortality at 6 months or 180 days of patients who had shockable rhythms $(\mathrm{n}=275 ; \mathrm{RR}=0.74 ; 95 \% \mathrm{CI}$, $0.58-0.95 ; p=0.02$ ).

\section{Impact on neurological function}

The overall effect of $\mathrm{MIH}$ on neurological function at hospital discharge was estimated from five trials, which included a total of 1372 patients. No evidence of a publication bias was observed following a funnel plot assessment (Additional file 3: Figure S2a), but there was significant heterogeneity $(p=0.002)$ and substantial heterogeneity $\left(\mathrm{I}^{2}=76 \%\right)$ among the trials (Fig. 4a). Based on a random-effects model, we found that MIH promotes better outcomes of neurological function at hospital discharge $(\mathrm{RR}=0.80 ; 95 \% \mathrm{CI}, 0.64-0.98 ; p=0.04)$. Interestingly, similar to the effect of $\mathrm{MIH}$ on mortality, the subgroup analysis showed that MIH could also improve the neurological function of patients with shockable rhythms $(\mathrm{n}=350 ; \mathrm{RR}=0.73 ; 95 \% \mathrm{CI}, 0.60-$ $0.88 ; p=0.001)$, but not those with non-shockable rhythms ( $\mathrm{n}=30$; RR = 0.88; $95 \%$ CI, 0.77-1.10; $p=0.26$ ).

The overall effect of $\mathrm{MIH}$ on neurological function at 6 months or 180 days was estimated from only three trials of 1348 patients. No evidence of a publication bias was observed following a funnel plot assessment 
Table 1 Characteristics of the included trials

\begin{tabular}{|c|c|c|c|c|c|c|c|c|c|}
\hline & Duration & Participants & $\begin{array}{l}\text { Experimental } \\
\text { intervention }\end{array}$ & Control intervention & Inclusion criteria & Exclusion criteria & $\begin{array}{l}\text { Follow-up } \\
\text { time }\end{array}$ & $\begin{array}{l}\text { Patients } \\
\text { screened (n) }\end{array}$ & $\begin{array}{l}\text { Patients } \\
\text { included (n) }\end{array}$ \\
\hline $\begin{array}{l}\text { Mori } 2000 \\
\text { (abstract) [20] }\end{array}$ & Not reported & $\begin{array}{l}\text { OHCA patients with } \\
\text { GCS }<8\end{array}$ & $\begin{array}{l}\text { MIH to } 32-34^{\circ} \mathrm{C} \\
\text { for } 72 \mathrm{~h} \text {, method } \\
\text { of cooling not } \\
\text { described, rewarming } \\
\text { rate not reported }\end{array}$ & $\begin{array}{l}36^{\circ} \mathrm{C} \text { for } 72 \mathrm{~h} \text {, } \\
\text { method of } \\
\text { temperature control } \\
\text { not described }\end{array}$ & OHCA and GCS $<8$ & Not defined & 1 month & Not reported & 54 \\
\hline $\begin{array}{l}\text { Hachimi-Idrissi } \\
2001 \text { [22] }\end{array}$ & 6 months & $\begin{array}{l}\text { Unconscious OHCA } \\
\text { patients, cardiac cause } \\
\text { of arrest, initial rhythm } \\
\text { asystole of PEA }\end{array}$ & $\begin{array}{l}\text { Helmet cooling to } 34^{\circ} \mathrm{C} \text {, } \\
\text { when temperature of } \\
34^{\circ} \mathrm{C} \text { achieved or more } \\
\text { than } 4 \mathrm{~h} \text { elapsed from } \\
\text { start of cooling, passive } \\
\text { rewarming for } 8 \mathrm{~h}\end{array}$ & $\begin{array}{l}\text { Standard ICU care, } \\
\text { acetaminophen if } \\
\text { temperature over } \\
38^{\circ} \mathrm{C}\end{array}$ & $\begin{array}{l}\text { OHCA of cardiac } \\
\text { origin asystole or } \\
\text { PEA as initial rhythm, } \\
>18 \text { years, temp } \\
>30^{\circ} \mathrm{C} \text {, GCS }<7\end{array}$ & $\begin{array}{l}\text { Pregnancy, } \\
\text { coagulopathy, } \\
\text { CNS antidepressant } \\
\text { medication before } \\
\text { CA, cardiogenic } \\
\text { shock (MAP <60), } \\
\text { GCS } \geq 7\end{array}$ & 14 days & Not reported & 30 \\
\hline HACA 2002 [7] & 65 months & $\begin{array}{l}\text { Unconscious CA } \\
\text { patients, cardiac cause } \\
\text { of arrest, initial rhythm } \\
\text { VF or non-perfusing VT }\end{array}$ & $\begin{array}{l}\text { Air cooling induced } \\
\text { hypothermia to } 33^{\circ} \mathrm{C} \\
\text { for } 24 \mathrm{~h} \text {, passive } \\
\text { rewarming for } 8 \mathrm{~h}\end{array}$ & $\begin{array}{l}\text { Standard ICU care, } \\
\text { no temperature } \\
\text { control }\end{array}$ & $\begin{array}{l}\text { Witnessed CA of } \\
\text { cardiac origin, VF } \\
\text { or non-perfusing } \\
\text { VT as initial rhythm, } \\
18-75 \text { years, } 5-15 \\
\text { min from arrest to } \\
\text { CPR and < } 60 \text { min } \\
\text { to ROSC }\end{array}$ & $\begin{array}{l}<30{ }^{\circ} \mathrm{C} \text {, coma } \\
\text { because of drugs } \\
\text { before CA, pregnancy, } \\
\text { response to verbal } \\
\text { command, MAP < } 60 \\
\text { for }>30 \text { min, hypoxemia } \\
>15 \text { min, terminal } \\
\text { illness, factors making } \\
\text { follow-up unlikely, } \\
\text { coagulopathy, other } \\
\text { study, CA after arrival } \\
\text { of medical personnel }\end{array}$ & 6 months & 3551 & 275 \\
\hline Bernard 2002 [6] & 33 months & $\begin{array}{l}\text { Unconscious OHCA } \\
\text { patients, cardiac cause } \\
\text { of arrest, initial rhythm } \\
\text { VF or VT }\end{array}$ & $\begin{array}{l}\text { Ice-pack induced } \\
\text { hypothermia to } 33^{\circ} \mathrm{C} \\
\text { for } 12 \mathrm{~h} \text { (started prior } \\
\text { to hospital admission), } \\
\text { active rewarming for } \\
6 \mathrm{~h}\end{array}$ & $\begin{array}{l}\text { Standard ICU care, } \\
\text { no temperature } \\
\text { control }\end{array}$ & $\begin{array}{l}\text { OHCA with VF as } \\
\text { initial rhythm, } \\
\text { persistent coma }\end{array}$ & $\begin{array}{l}<18 \text { years for men, } \\
<50 \text { years for women, } \\
\text { cardiogenic shock } \\
<90 \text { SBP despite } \\
\text { epinephrine, other } \\
\text { causes of coma than } \\
\text { CA, no available ICU } \\
\text { bed }\end{array}$ & $\begin{array}{l}\text { Hospital } \\
\text { discharge }\end{array}$ & $\begin{array}{l}\text { Not reported } \\
\text { (84 eligible) }\end{array}$ & 77 \\
\hline Laurent 2005 [21] & 23 months & $\begin{array}{l}\text { Unconscious OHCA } \\
\text { patients, cardiac cause } \\
\text { of arrest, initial rhythm } \\
\text { VF or asystole }\end{array}$ & $\begin{array}{l}\mathrm{CWH} \text { to } 32-33^{\circ} \mathrm{C} \\
(\mathrm{CWH} \text { for } 8 \mathrm{~h} \text { and } \\
\text { surface cooling for } \\
16 \mathrm{~h} \text { ), passive } \\
\text { rewarming }\end{array}$ & $\begin{array}{l}\mathrm{CWH} \text { maintaining } \\
37^{\circ} \mathrm{C} \text { for } 8 \mathrm{~h} \text {, thereafter } \\
\text { no temperature control }\end{array}$ & $\begin{array}{l}\text { OHCA of cardiac } \\
\text { origin, VF of asystole, } \\
18-75 \text { years, }<10 \text { min } \\
\text { to start of CPR, } \\
<50 \text { min to ROSC }\end{array}$ & $\begin{array}{l}\text { Pregnancy, response } \\
\text { to verbal command, } \\
\text { terminal illness } \\
\text { before CA }\end{array}$ & 6 months & 244 & 42 \\
\hline
\end{tabular}


Table 1 Characteristics of the included trials (Continued)

\begin{tabular}{|c|c|c|c|c|c|c|c|c|c|}
\hline Nielsen 2013 [11] & 27 months & $\begin{array}{l}\text { OHCA patients with } \\
\text { GCS }<8\end{array}$ & $\begin{array}{l}\text { Ice-cold fluids, ice packs, } \\
\text { and intravascular or } \\
\text { surface temperature- } \\
\text { management devices } \\
\text { induced hypothermia } \\
\text { to } 33^{\circ} \mathrm{C} \text { for } 28 \mathrm{~h} \text {, } \\
\text { gradual rewarming to } \\
37^{\circ} \mathrm{C} \text { in hourly } \\
\text { increments of } 0.5^{\circ} \mathrm{C} \text {, } \\
<37.5^{\circ} \mathrm{C} \text { for unconscious } \\
\text { patients until } 72 \text { hours } \\
\text { after CA }\end{array}$ & $\begin{array}{l}\text { Ice-cold fluids, ice } \\
\text { packs, and intravascular } \\
\text { or surface temperature- } \\
\text { management devices } \\
\text { induced hypothermia } \\
\text { to } 36^{\circ} \mathrm{C} \text { for } 28 \mathrm{~h} \text {, } \\
\text { gradual rewarming } \\
\text { to } 37^{\circ} \mathrm{C} \text { in hourly } \\
\text { increments of } 0.5^{\circ} \mathrm{C} \text {, } \\
<37.5^{\circ} \mathrm{C} \text { for } \\
\text { unconscious patients } \\
\text { until } 72 \text { hours after CA }\end{array}$ & $\begin{array}{l}\text { OHCA of cardiac } \\
\text { origin, GCS }<8, \\
>18 \text { years, }>20 \text { min } \\
\text { of spontaneous } \\
\text { circulation after } \\
\text { resuscitation }\end{array}$ & $\begin{array}{l}\text { An interval from the } \\
\text { ROSC to screening } \\
>240 \text { min, unwitnessed } \\
\text { arrest with asystole as } \\
\text { the initial rhythm, } \\
\text { suspected or known } \\
\text { acute intracranial } \\
\text { haemorrhage or } \\
\text { stroke, }<30^{\circ} \mathrm{C}\end{array}$ & 180 days & 950 & 939 \\
\hline
\end{tabular}

CA Cardiac arrest, CNS Central nervous system, CPR Cardiopulmonary resuscitation, CVVH Continuous veno-venous filtration, GCS Glasgow Coma Score, HACA Hypothermia After Cardiac Arrest, ICU Intensive care unit, MAP Mean arterial pressure, MIH Mild induced hypothermia, OHCA Out-of-hospital cardiac arrest, PEA Pulseless electrical activity, ROSC Return of spontaneous circulation, SBP Systolic blood pressure, VF Ventricular fibrillation, VT Ventricular tachycardia 


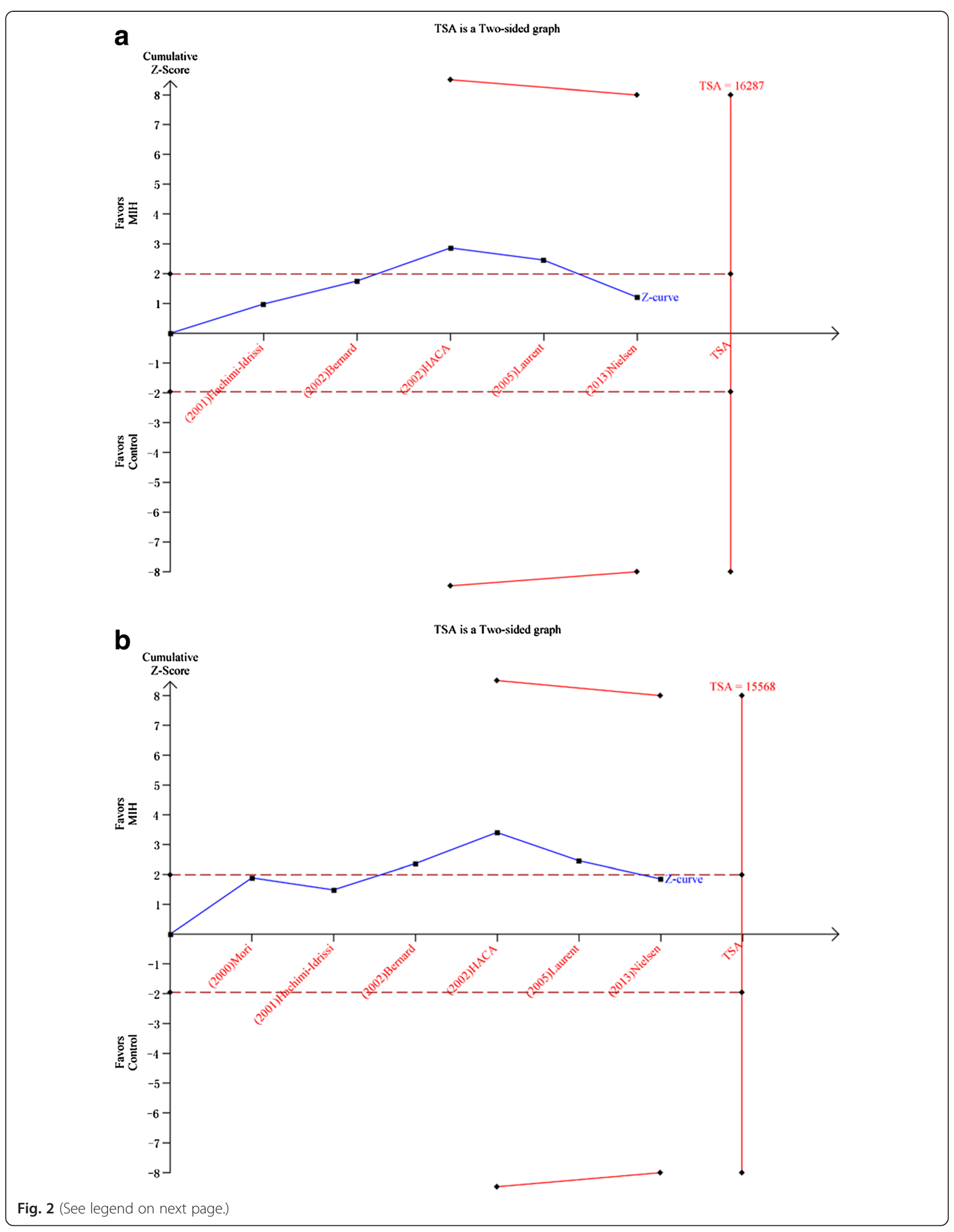


(See figure on previous page.)

Fig. 2 a. Trial sequential analysis for a relative risk reduction of all-cause mortality of $5.8 \%$ of hypothermia after cardiac arrest in five trials with 1363 patients reporting mortality. A required diversity-adjusted information size of 16,287 patients was calculated based on a control event proportion of $51.0 \%$, a hypothermia-induced relative risk reduction of mortality of $5.8 \%$ suggested by all trials, $a=0.05$ two-sided, $\beta=0.20$ (power $=80 \%$ ), and diversity $D^{2}=60 \%$. The cumulated Z-curve (blue) crosses the traditional boundary $(p=0.05)$ but not the trial sequential monitoring boundary, indicating lack of firm evidence for a beneficial effect of $5.8 \%$ relative risk reduction of the intervention when the analysis is adjusted for repetitive testing on accumulating data. There is insufficient information to reject or detect an intervention effect of $5.8 \%$ relative risk reduction of all-cause mortality as the required information size is not yet reached. $\mathbf{b}$. Trial sequential analysis (TSA) for a relative risk reduction of $7.29 \%$ of hypothermia after cardiac arrest in six trials with 1409 patients reporting neurological function. A required diversity-adjusted information size of 15,568 patients was calculated based on a control event proportion of $56.9 \%$, a hypothermia-induced relative risk reduction of poor neurological function of $7.29 \%$ suggested by all trials, $a=0.05$ two-sided, $\beta=0.20$ (power $=80 \%$ ), and diversity $D^{2}=79 \%$. The cumulated Z-curve (blue) crosses the traditional boundary $(p=0.05)$ but not the trial sequential monitoring boundary, indicating lack of firm evidence for a beneficial effect of $7.29 \%$ relative risk reduction of the intervention when the analysis is adjusted for repetitive testing on accumulating data. There is insufficient information to reject or detect an intervention effect of $7.29 \%$ relative risk reduction of poor neurological outcome as the required information size is not yet reached

(Additional file 3: Figure S2b), but there was significant heterogeneity $(p=0.03)$ and substantial heterogeneity $\left(\mathrm{I}^{2}=72 \%\right)$ among the trials (Fig. $\left.4 \mathrm{~b}\right)$. MIH did not promote better outcomes of neurological function at 6 months or 180 days based on a random-effects model $(\mathrm{RR}=0.94 ; 95 \% \mathrm{CI}, 0.72-1.23 ; p=0.67)$. However, the subgroup analysis showed that MIH could also improve the neurological function of patients with shockable rhythms $(\mathrm{n}=273$; $\mathrm{RR}=0.74 ; 95 \% \mathrm{CI}$, $0.59-0.93 ; p=0.01$ ).

\section{Impact on complications}

Five trials reported the adverse effects of MIH but only four of them were evaluated to estimate the overall effect of $\mathrm{MIH}$ on the incidence of complications (Fig. 5) because the trial of Bernard et al. [6] did not report the incidence of the complications. The complications associated with MIH that were reported in the trials included pneumonia, sepsis, and arrhythmia, among others. The incidence of complications in the MIH group was significantly higher than that in the control group ( $\mathrm{RR}=1.14 ; 95 \% \mathrm{CI}, 1.05-1.25 ; p=0.003$ ). No evidence of a publication bias was observed following a funnel plot assessment (Additional file 4: Figure S3).

\section{Risk of bias in included studies}

We assessed each included trial by the mode of randomization, allocation concealment, level of blinding and loss to follow-up (Fig. 6).

\section{Summary of evidence according to GRADE}

Randomised trials are rated high on the GRADE scale. There were variable risks of bias in all the trials, leading us to downgrade the quality of the evidence. Due to one trial [11], there was some inconsistency among the trials. One trial [7] included only less than $8 \%$ of the screened patients and one trial [22] included only CA patients with pulseless electrical activity and asystole. Our application of GRADE methodology led us to conclude that the accumulated evidence is of low quality for mortality and neurological outcome. For a GRADE profile see Tables 2 and 3.

\section{Sensitivity analysis}

As shown in Fig. $7 \mathrm{a}$ and $\mathrm{b}$, the study conducted by Nielsen et al. [11] was completely out of range of the others and probably contributed to the heterogeneity, indicating lack of reliability in our conclusions.

\section{Impact of MIH versus no target temperature on mortality and neurological function of CA patients}

Among the included studies, four studies of 423 patients reported the mortality and four studies of 421 patients reported neurological function at 6 months and at hospital discharge. We detected no evidence of a publication bias after a funnel plot analysis (Additional file 5: Figure S4a and b). The mortality rate was significantly different between the MIH group and the no target temperature group ( $\mathrm{RR}=0.77 ; 95 \% \mathrm{CI}, 0.65-0.92 ; p=0.003)$, and so was the neurological function between them $(R R=0.76$; $95 \%$ CI, 0.65-0.89; $p<0.001$ ) (Additional file 6: Figure S5a and b).

\section{Impact of MIH versus TTM on mortality and neurological function of CA patients}

Among the included studies, only two studies of $980 \mathrm{pa}-$ tients reported the mortality and three studies of 1029 patients reported neurological function at the end of trial and at hospital discharge. We detected no evidence of a publication bias after a funnel plot analysis, but there was significant heterogeneity $(p=0.005)$ and substantial heterogeneity $\left(\mathrm{I}^{2}=81 \%\right)$ among the trials in the effect on neurological function (Additional file 7 : Figure S6a and b). The mortality rate was not significantly different between the MIH group and the TTM group $(\mathrm{RR}=1.03 ; 95 \% \mathrm{CI}, 0.91-1.16 ; p=0.67)$, and neither was the neurological function between them $(R R=0.89$; $95 \%$ CI, 0.59-1.35; $p=0.58$ ) (Additional file 8: Figure S7a and b). 


\section{Discussion}

$\mathrm{MIH}$ is one of the most common treatments for patients who experience CA. However, whether it can improve the prognosis of patients with CA is still controversial. To further evaluate the effects of MIH compared to controls with temperature $>34{ }^{\circ} \mathrm{C}$ in adult patients after CA on mortality and neurologic performance, a meta-analysis of RCTs was performed. The results suggest that: 1) MIH did not significantly decrease the mortality at hospital discharge or at 6 months or 180 days, but it did reduce the mortality of patients with shockable rhythms at hospital discharge and at 6 months or 180 days; 2) MIH can improve the outcome of neurological function at hospital discharge especially in those patients with shockable rhythm but not at 6 months or 180 days; 3) The incidence of complications in the MIH group was significantly higher than that in the control group; 4) All of the intervention effects above could not be confirmed or rejected by TSA.

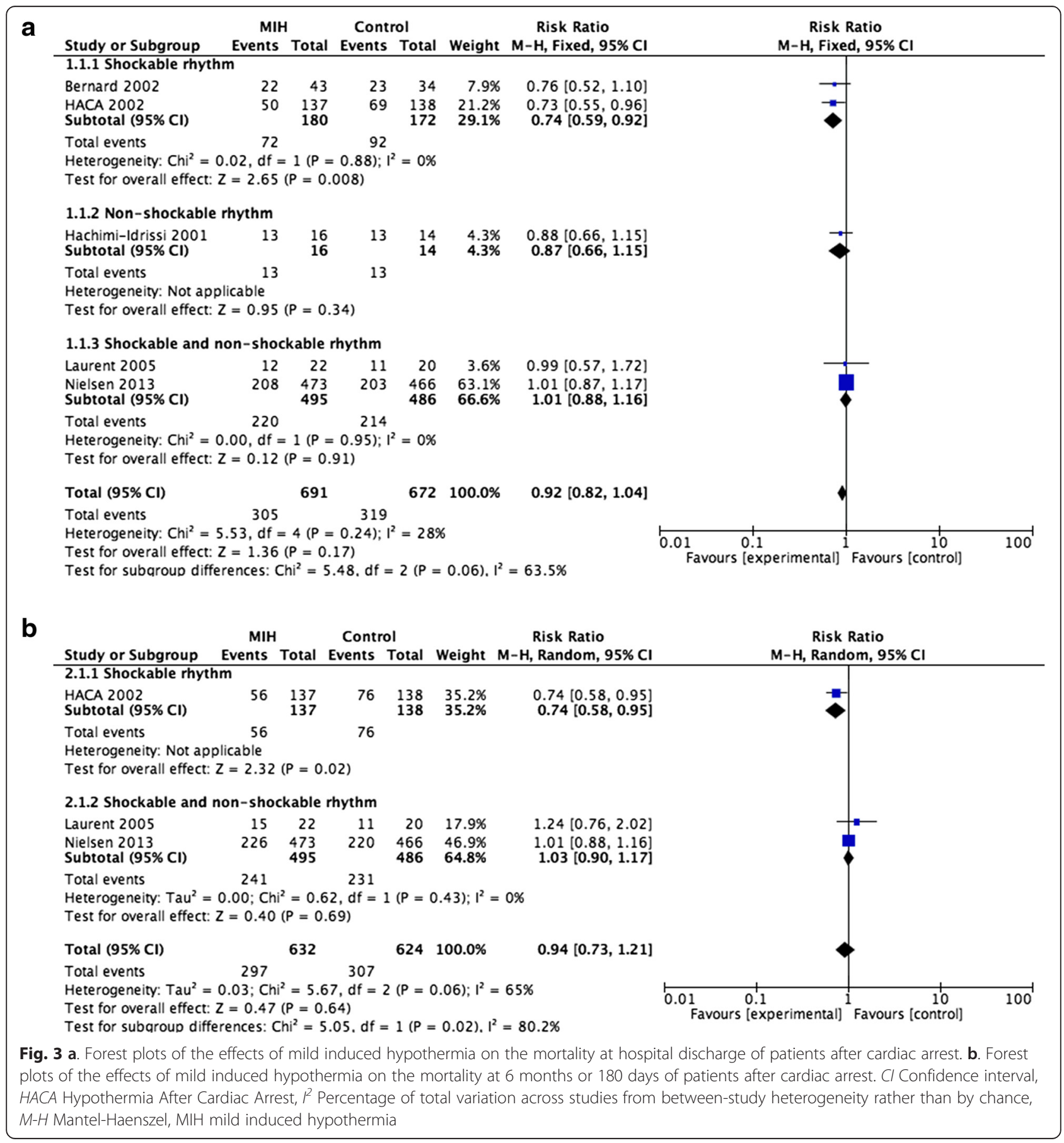




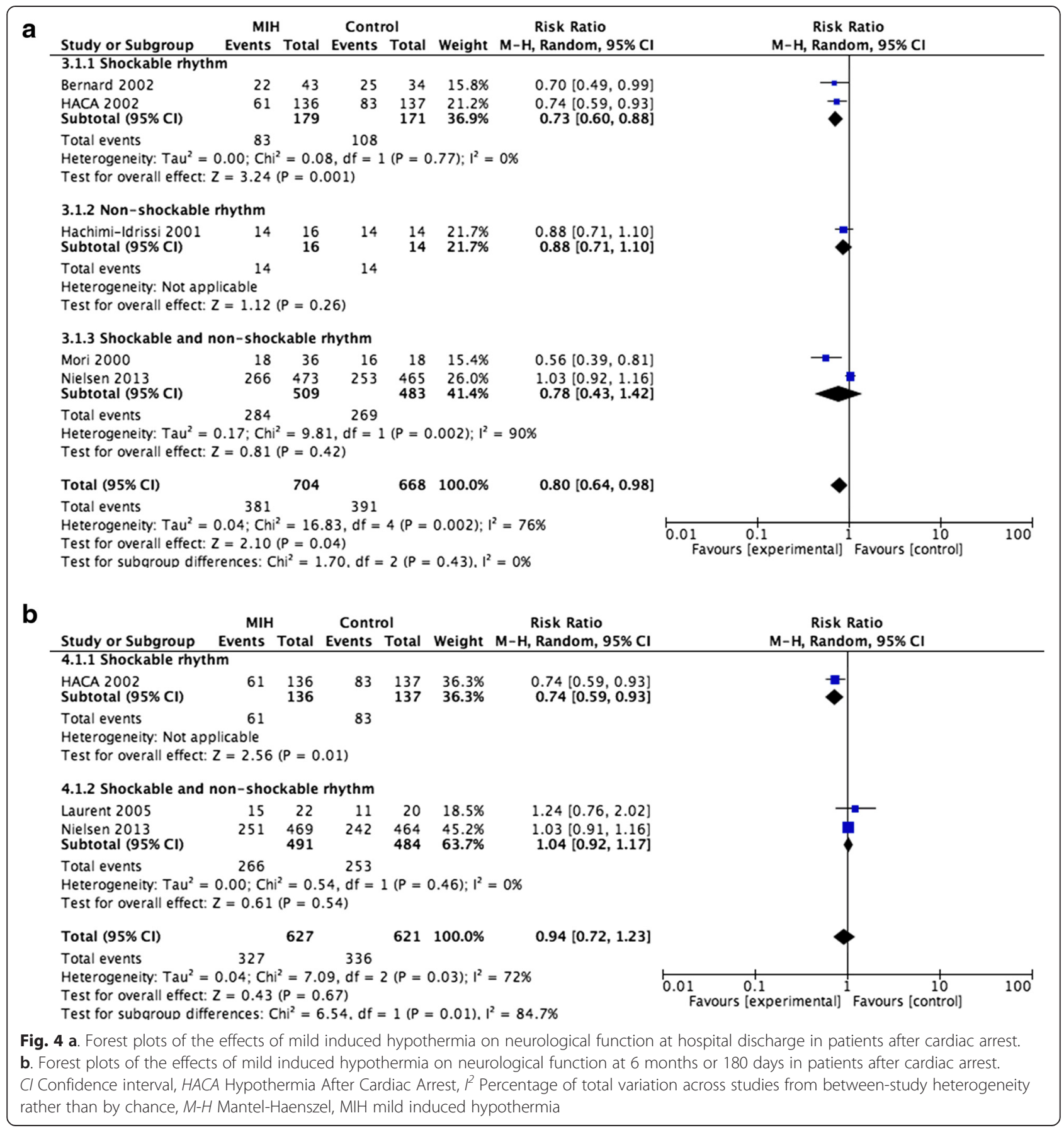

The results of the meta-analysis were different from previous studies investigating possible beneficial effects of MIH after CA. To our knowledge, our study is the first meta-analysis that separated the patients into shockable and non-shockable rhythm due to the initial rhythms. Moreover, our study also included the study by Nielsen et al. [11] that has a very low risk of bias. In contrast to the last Cochrane reviews [12], we did not find a reduced mortality comparing MIH and TTM. Furthermore, Cochrane reviews [12] did not report any outcome at 6 months. In the meta-analysis by Nielsen et al. [10] in 2011, the data on main outcomes were also pooled together. In our meta-analysis, we used TSA to evaluate type I errors which result from an increased risk of random error and repeated significance testing.

Heterogeneity in the control group makes this metaanalysis different from others. It is very clear to demonstrate the overall effects of MIH but imprecise to state the influences of the exact range of temperature when mixing the controls with any body temperature $>34{ }^{\circ} \mathrm{C}$ 


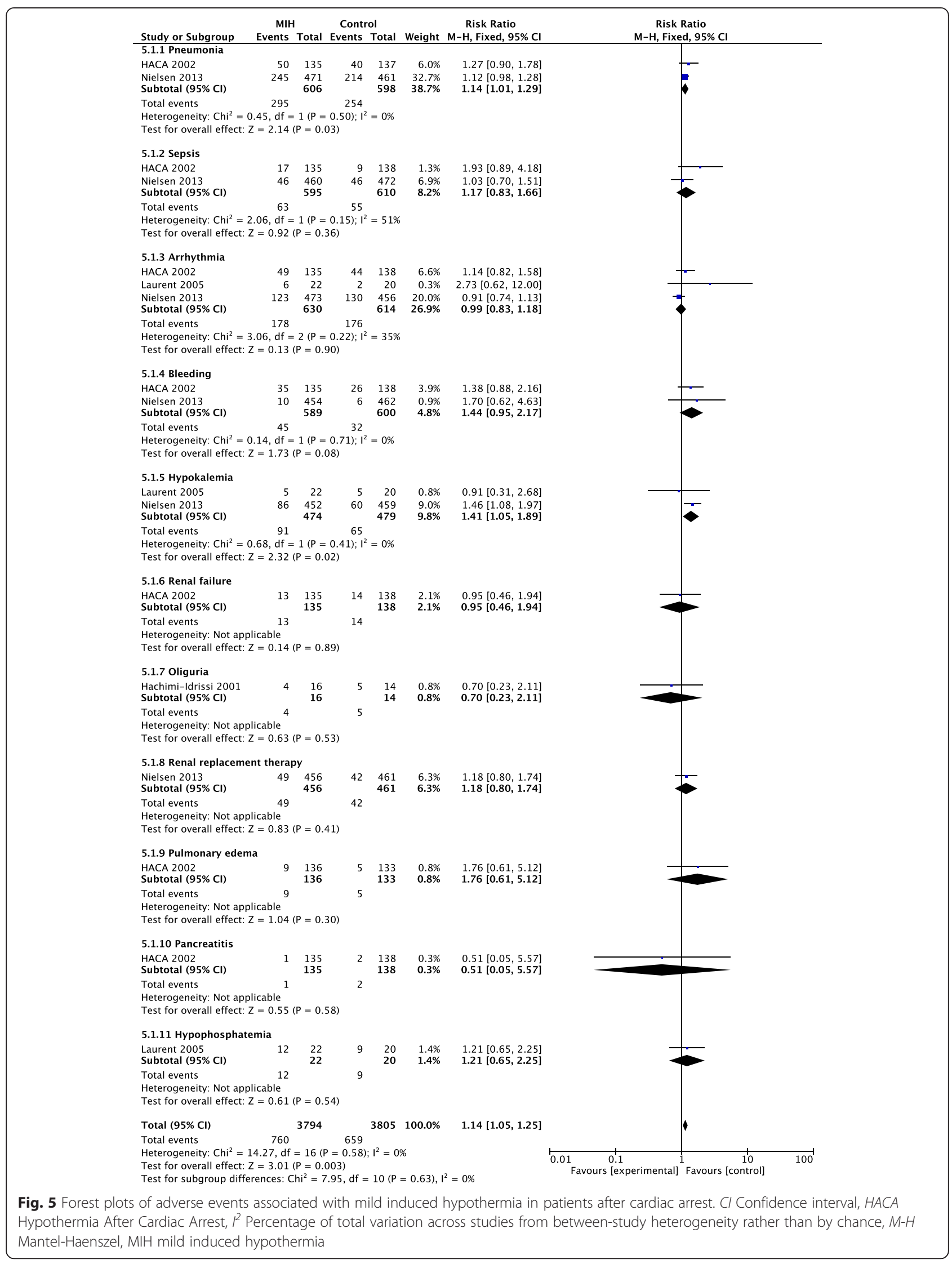



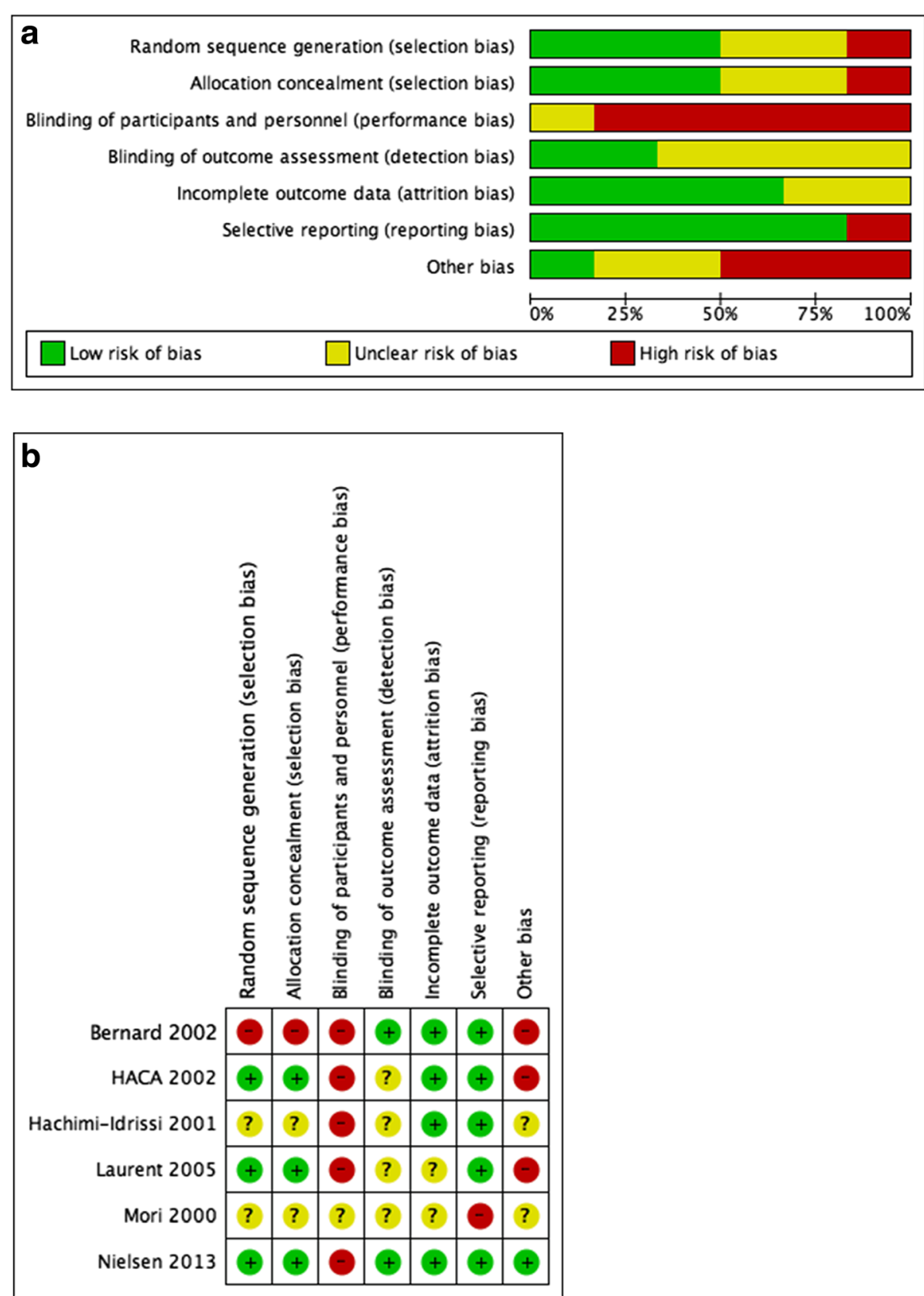

Fig. 6 a. Risk of bias graph. Review authors' judgements about each risk of bias item presented as percentages across all included studies. b. Risk of bias summary. Review authors' judgements about each risk of bias item for each included study

together. However, when separating the temperature control into no target temperature and TTM in the subgroup analysis, it shows that patients treated with $\mathrm{MIH}$ have a better outcome than patients treated with no target temperature. Because of the heterogeneous control in the meta-analysis, it does not mean that temperature does not need to be managed at all for CA patients. Current 2015 American Heart Association Guidelines Update for Cardiopulmonary Resuscitation and Emergency
Cardiovascular Care recommend that all comatose adult patients with ROSC after CA should have TTM, with a target temperature between $32{ }^{\circ} \mathrm{C}$ and $36{ }^{\circ} \mathrm{C}$ selected and achieved, then maintained constantly for at least 24 hours [23]. Therefore, further trials are needed to elucidate the optimal target temperature of $\mathrm{MIH}$ after CA.

That MIH cannot improve the mortality of patients with CA may be due to the heterogeneity of patients. Whole-body low temperature treatment during 
Table 2 Summary of findings for the main comparison

\begin{tabular}{|c|c|c|c|c|c|c|}
\hline \multicolumn{7}{|c|}{ MIH compared to control for cardiac arrest patients } \\
\hline \multicolumn{7}{|l|}{ Setting: } \\
\hline \multicolumn{7}{|l|}{ Intervention: MIH } \\
\hline \multicolumn{7}{|l|}{ Comparison: Control } \\
\hline \multicolumn{7}{|l|}{$\begin{array}{l}\text { Patient or population: cardiac } \\
\text { arrest patients }\end{array}$} \\
\hline \multicolumn{7}{|l|}{ Setting: } \\
\hline \multicolumn{7}{|l|}{ Intervention: $\mathrm{MIH}$} \\
\hline \multicolumn{7}{|l|}{ Comparison: Control } \\
\hline \multirow[t]{2}{*}{ Outcomes } & \multicolumn{2}{|c|}{$\begin{array}{l}\text { Anticipated absolute effects }{ }^{a} \\
(95 \% \mathrm{Cl})\end{array}$} & Relative effect (95\% Cl) & $\begin{array}{l}\text { No. of participants } \\
\text { (studies) }\end{array}$ & $\begin{array}{l}\text { Quality of the } \\
\text { evidence (GRADE) }\end{array}$ & Comments \\
\hline & Risk with control & Risk with $\mathrm{MIH}$ & & & & \\
\hline \multirow{4}{*}{$\begin{array}{l}\text { Mortality (follow-up } 180 \text { days } \\
\text { or hospital discharge) }\end{array}$} & Study population & & \multirow[t]{4}{*}{ RR 0.94 (0.84 to 1.04) } & \multirow[t]{4}{*}{1363 (5 RCTs) } & \multirow{4}{*}{\multicolumn{2}{|c|}{ 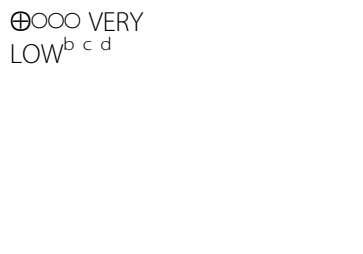 }} \\
\hline & 510 per 1000 & $\begin{array}{l}480 \text { per } 1000 \\
(429 \text { to } 531)\end{array}$ & & & & \\
\hline & Moderate & & & & & \\
\hline & 551 per 1000 & $\begin{array}{l}518 \text { per } 1000 \\
\text { (463 to } 573)\end{array}$ & & & & \\
\hline \multirow{4}{*}{$\begin{array}{l}\text { Neurological outcome (follow-up } \\
180 \text { days or hospital discharge) }\end{array}$} & Study population & & \multirow[t]{4}{*}{ RR 0.83 (0.68 to 1.01) } & \multirow[t]{4}{*}{1409 (6 RCTs) } & \multirow{4}{*}{\multicolumn{2}{|c|}{ 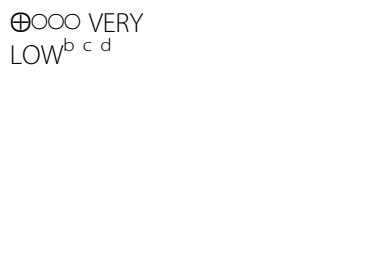 }} \\
\hline & 569 per 1000 & $\begin{array}{l}472 \text { per } 1000 \\
\text { (387 to } 575)\end{array}$ & & & & \\
\hline & Moderate & & & & & \\
\hline & 671 per 1000 & $\begin{array}{l}557 \text { per } 1000 \\
\text { (456 to } 677)\end{array}$ & & & & \\
\hline \multicolumn{7}{|c|}{$\begin{array}{l}\text { GRADE Working Group grades of evidence: high quality-we are very confident that the true effect lies close to that of the estimate of the effect; moderate } \\
\text { quality - we are moderately confident in the effect estimate (the true effect is likely to be close to the estimate of the effect, but there is a possibility that it is } \\
\text { substantially different); low quality - our confidence in the effect estimate is limited (the true effect may be substantially different from the estimate of the effect); } \\
\text { very low quality - we have very little confidence in the effect estimate (the true effect is likely to be substantially different from the estimate of effect). } \\
\text { a The risk in the intervention group (and its } 95 \% \mathrm{Cl} \text { ) is based on the assumed risk in the comparison group and the relative effect of the intervention (and its } \\
95 \% \mathrm{Cl} \text { ) } \\
\text { bAll trials were with substantial risk of bias } \\
\text { cOne trial accounted for the largest part among all the trials and probably contributed to the heterogeneity } \\
\text { dOne trial included only less than } 8 \% \text { of the screened patients. One trial included only cardiac arrest patients with pulseless electrical activity and asystole } \\
\text { CI Confidence interval, MIH Mild induced hypothermia, RCT Randomised controlled trial, RR Risk ratio }\end{array}$} \\
\hline
\end{tabular}

resuscitation may interfere with organ function, and thus the benefits of MIH should be balanced with its side effects [24]. Moreover, large differences remain in patients with CA of different severity, and the potential pros and cons of temperature intervention are not equivalent in different patients. Recently, a large observational study has shown that hypothermia was independently associated with an improved outcome at hospital discharge in patients who presented with ventricular fibrillation/ventricular tachycardia but not in patients with non-shockable rhythms [25]. Therefore, if the time and degree of hypothermia could match the severity of the brain injury in patients with CA, these patients may also benefit from the MIH. However, these patients were not screened before each study, and a "one-size-fits-all" treatment approach makes it impossible to improve the outcomes of patients who require this treatment.

The selection of the temperature and implementation time of $\mathrm{MIH}$ may also affect the improvement of neurological function. The primary protective effect of $\mathrm{MIH}$ is to reduce brain metabolism of free radicals, to inhibit the release of excitatory amino acids, to attenuate the immune response in reperfusion and to inhibit apoptosis of brain cells [26]. Lopez-de-Sa and colleagues have suggested that a $32{ }^{\circ} \mathrm{C}$ cooling level may be associated with lower mortality and incidence of seizures compared with that of a $34{ }^{\circ} \mathrm{C}$ cooling level in patients who experienced an OHCA secondary to a shockable rhythm [27]. Moreover, in animal models of $\mathrm{CA}$, the implementation of low temperature treatment $\left(33^{\circ} \mathrm{C} \pm 1{ }^{\circ} \mathrm{C}\right.$ in 4 hours after ROSC) can improve mortality and neurological function $[28,29]$. In addition, it has been demonstrated that prehospital therapeutic hypothermia after CA can decrease temperature on hospital admission [30]. Therefore, a quicker induction of hypothermia may prevent a cascade effect of reperfusion injury, inflammatory attack and cell degeneration. However, current guidelines for CA do not recommend routine prehospital cooling with 
Table 3 GRADE profile for assessing quality of evidence for mild induced hypothermia after out-of-hospital cardiac arrest

\begin{tabular}{|c|c|c|c|c|c|c|c|c|c|c|c|c|}
\hline \multicolumn{7}{|c|}{ Quality assessment } & \multicolumn{2}{|c|}{ No. of patients } & \multicolumn{2}{|l|}{ Effect } & \multirow[t]{2}{*}{ Quality } & \multirow[t]{2}{*}{ Importanc } \\
\hline No. of studies & Study design & Risk of bias & Inconsistency & Indirectness & Imprecision & Other considerations & $\mathrm{MIH}$ & Control & Relative $(95 \% \mathrm{Cl})$ & Absolute $(95 \% \mathrm{Cl})$ & & \\
\hline \multicolumn{13}{|c|}{ Mortality (follow-up 180 days or hospital discharge) } \\
\hline \multirow[t]{2}{*}{5} & \multirow[t]{2}{*}{$\begin{array}{l}\text { Randomised } \\
\text { trials }\end{array}$} & \multirow[t]{2}{*}{ Serious $^{\mathrm{a}}$} & \multirow[t]{2}{*}{ Serious $^{\mathrm{b}}$} & \multirow[t]{2}{*}{ Serious $^{c}$} & \multirow[t]{2}{*}{ Not serious } & \multirow[t]{2}{*}{ None } & \multirow[t]{2}{*}{$\begin{array}{l}332 / 691 \\
(48.0 \%)\end{array}$} & $\begin{array}{l}343 / 672 \\
(51.0 \%)\end{array}$ & \multirow[t]{2}{*}{$\begin{array}{l}\text { RR } 0.94 \\
(0.84-1.04)\end{array}$} & $\begin{array}{l}31 \text { fewer per } 1000 \\
\text { (from } 20 \text { more to } \\
82 \text { fewer) }\end{array}$ & \multirow[t]{2}{*}{$\begin{array}{l}\text { ФOOO VERY } \\
\text { LOW }^{\mathrm{b}} \mathrm{c} c\end{array}$} & \multirow[t]{2}{*}{ CRITICAL } \\
\hline & & & & & & & & $55.1 \%$ & & $\begin{array}{l}33 \text { fewer per } 1000 \\
\text { (from } 22 \text { more to } \\
88 \text { fewer) }\end{array}$ & & \\
\hline \multicolumn{13}{|c|}{ Neurological outcome (follow-up 180 days or hospital discharge) } \\
\hline \multirow[t]{2}{*}{6} & \multirow[t]{2}{*}{$\begin{array}{l}\text { Randomised } \\
\text { trials }\end{array}$} & \multirow[t]{2}{*}{ Serious $^{\mathrm{a}}$} & \multirow[t]{2}{*}{ Serious ${ }^{\mathrm{b}}$} & \multirow[t]{2}{*}{ Serious $^{c}$} & \multirow[t]{2}{*}{ Not serious } & \multirow[t]{2}{*}{ None } & \multirow[t]{2}{*}{$\begin{array}{l}381 / 722 \\
(52.8 \%)\end{array}$} & $\begin{array}{l}391 / 687 \\
(56.9 \%)\end{array}$ & \multirow[t]{2}{*}{$\begin{array}{l}\text { RR } 0.83 \\
(0.68-1.01)\end{array}$} & $\begin{array}{l}97 \text { fewer per } 1000 \\
\text { (from } 6 \text { more to } \\
182 \text { fewer) }\end{array}$ & \multirow[t]{2}{*}{$\begin{array}{l}\text { ФOOO VERY } \\
\text { LOW }^{\mathrm{a} b c}\end{array}$} & \multirow[t]{2}{*}{ CRITICAL } \\
\hline & & & & & & & & $67.1 \%$ & & $\begin{array}{l}114 \text { fewer per } 1000 \\
\text { (from } 7 \text { more to } \\
215 \text { fewer) }\end{array}$ & & \\
\hline
\end{tabular}

GRADE Working Group grades of evidence: high quality-we are very confident that the true effect lies close to that of the estimate of the effect; moderate quality-we are moderately confident in the effect estimate (the true effect is likely to be close to the estimate of the effect, but there is a possibility that it is substantially different); low quality-our confidence in the effect estimate is limited (the true effect may be substantially different from the estimate of the effect); very low quality- we have very little confidence in the effect estimate (the true effect is likely to be substantially different from the estimate of effect). substantilly differte

${ }^{b}$ One trial accounted for the largest part among all the trials and probably contributed to the heterogeneity

cOne trial included only less than $8 \%$ of the screened patients. One trial included only cardiac arrest patients with pulseless electrical activity and asystole CI Confidence interval, MIH Mild induced hypothermia, RR Risk ratio 

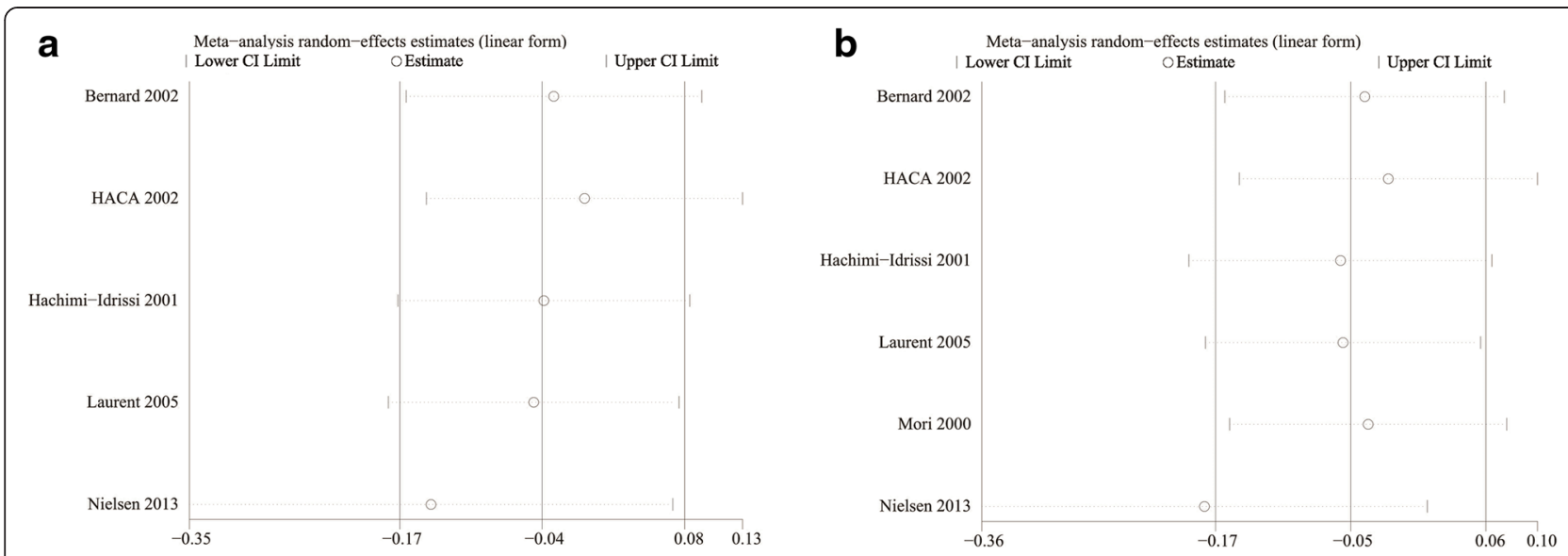

Fig. 7 a. Sensitivity analysis of the effects of mild induced hypothermia on the mortality of patients after cardiac arrest for all included studies. b. Sensitivity analysis of the effects of mild induced hypothermia on the neurological function of patients after cardiac arrest for all included studies. Cl Confidence interval, HACA Hypothermia After Cardiac Arrest

rapid infusion of cold intravenous fluids after ROSC [23]. MIH also interferes with numerous physiological and pathological processes; therefore, MIH might have unfavourable effects in patients who receive it and potentially put them at risk for adverse events.

Different cooling measurements may cause different complications and may reduce the efficacy of MIH. Surface and intravascular (invasive) cooling are the main measures for induction and maintenance of low body temperature. Compared with intravascular cooling, simple surface cooling seems to be associated with greater temperature fluctuations and more frequent overcooling, which may result in serious complications [31]. Nonetheless, intravascular cooling and surface cooling with automatic feedback systems allow for a more stable control of the temperature [32, 33]. Therefore, although no significant differences were observed in the complications between the low temperature and the normal temperature groups in patients with CA [34], the appropriate cooling measures could effectively prevent potential complications associated with MIH. Many cooling methods currently exist in clinical practice, and the identification of the most effective and safe methods to induce hypothermia need to be confirmed by further research.

The avoidance of post-hypothermia fever (PHF) can effectively improve the prognosis of patients with CA. Two large RCTs were included in our meta-analysis, namely the study by Nielsen et al. [11] and the Hypothermia After Cardiac Arrest (HACA) study [7]. After a comparison of the two studies, the mortality of OHCA patients in Nielsen et al.'s study was lower than that of patients in the HACA study. This is likely related to control of the body temperature after MIH. Moreover, that no differences were observed in the outcomes of the two groups of patients in Nielsen et al.'s study seems to be associated with a prevention of PHF. In addition, in older trials of $\mathrm{MIH}$, many patients in the "normothermia" group actually became hyperthermic, which is deleterious for prognosis and recovery of neurological function in patients with $\mathrm{CA}$. Bro-Jeppesen and colleagues have shown that a PHF $\geq 38.5^{\circ} \mathrm{C}$ was associated with an increase in 30-day mortality, even after controlling for potential confounding factors [35]. Current guidelines also show that actively preventing fever in comatose patients after temperature management is reasonable [23]. Therefore, effectively avoiding PHF may benefit patients with CA.

It is worth mentioning that there is lack of firm evidence for a beneficial effect and an insufficient information size to reject the anticipated intervention effect. Thus, the question whether MIH is beneficial, neutral or harmful, for adult OHCA patients still needs an answer.

\section{Conclusions}

In summary, this meta-analysis of the available RCTs showed that MIH does not improve in- hospital, 6month or 180-day mortality in adult patients with CA. However, it is too early to completely negate the therapeutic effects of MIH in patients with CA. Future studies should pay particular attention to the temperature and the timing of $\mathrm{MIH}$, selection of patients, efficiency and security of cooling measures and the avoidance of PHF. Much more research is needed to optimise the strategy of MIH.

\section{Key messages}

- Mild induced hypothermia is believed to reduce mortality and neurological impairment after out-ofhospital cardiac arrest. However, a recently published trial did not provide evidence supporting this hypothesis. 
- Our study-level meta-analysis shows that treatment with mild induced hypothermia does not appear to improve the short-term or long-term mortality of adult patients with cardiac arrest.

- Mild induced hypothermia may have a possible beneficial effect for patients with shockable rhythms both in mortality and neurological function.

- Although mild induced hypothermia may result in some adverse events, it helped lead to better outcomes regarding neurological function in patients with cardiac arrest, especially those with shockable rhythms. Large-scale ongoing trials addressing this question may provide data better applicable to clinical practice.

\section{Additional files}

Additional file 1: Table S1. Search strategy for the Cochrane database. Table S2 Search strategy for other databases. (DOCX 63 kb)

Additional file 2: Figure S1. a. Funnel plots of the effects of mild induced hypothermia on the mortality at hospital discharge of patients after cardiac arrest. b. Funnel plots of the effects of mild induced hypothermia on the mortality at 6 months or 180 days of patients after cardiac arrest. (TIF $354 \mathrm{~kb}$ )

Additional file 3: Figure S2. a. Funnel plots of the effects of mild induced hypothermia on neurological function at hospital discharge in patients after cardiac arrest. b. Funnel plots of the effects of mild induced hypothermia on neurological function at 6 months or 180 days of patients after cardiac arrest. (TIF $344 \mathrm{~kb}$ )

Additional file 4: Figure S3. Funnel plots of adverse events associated with mild induced hypothermia in patients after cardiac arrest. (TIF $890 \mathrm{~kb}$ )

Additional file 5: Figure S4. a. Funnel plots of the effects of $\mathrm{MlH}$ compared with no target temperature on the mortality of patients after cardiac arrest. b. Funnel plots of the effects of $\mathrm{MIH}$ compared with no target temperature on neurological function of patients after cardiac arrest. (TIF $341 \mathrm{~kb})$

Additional file 6: Figure S5. a. Forest plots of the effects of $\mathrm{MIH}$ compared with no target temperature on the mortality of patients after cardiac arrest. b. Forest plots of the effects of $\mathrm{MIH}$ compared with no target temperature on neurological function of patients after cardiac arrest. (TIF 2865 kb)

Additional file 7: Figure S6. a. Funnel plots of the effects of MIH compared with target temperature management on the mortality of patients after cardiac arrest. b. Funnel plots of the effects of $\mathrm{MIH}$ compared with target temperature management on neurological function of patients after cardiac arrest. (TIF $340 \mathrm{~kb}$ )

Additional file 8: Figure S7. a. Forest plots of the effects of $\mathrm{MIH}$ compared with target temperature management on the mortality of patients after cardiac arrest. b. Forest plots of the effects of $\mathrm{MlH}$ compared with target temperature management on neurological function of patients after cardiac arrest. (TIF $2174 \mathrm{~kb}$ )

\section{Abbreviations}

CA: Cardiac arrest; Cl: Confidence interval; CPC: Cerebral performance category; CRRT: Continuous renal replacement therapy; DIS: Diversity-adjusted information size; HACA: Hypothermia After Cardiac Arrest; IHCA: In-hospital cardiac arrest; $\mathrm{M}-\mathrm{H}$ : Mantel-Haenszel; $\mathrm{MIH}$ : Mild induced hypothermia; OHCA: Out-of-hospital cardiac arrest; PHF: Post-hypothermia fever; RCT: Randomised controlled trial; ROSC: Return of spontaneous circulation; RR: Risk ratio; RRR: Relative risk reduction; TSA: Trial sequential analysis; TTM: Target temperature management.

\section{Competing interests}

The authors declare that they have no competing interests.

\section{Authors' contributions}

XWZ conducted the literature searches, study selection, data extraction, assessed study quality and prepared initial drafts of the manuscript. JFX revised the manuscript according to the advice from other authors. JFX and JXC reviewed abstracts, selected studies meeting inclusion criteria, extracted data, and assessed study quality. XWZ, YZH and FMG input data and performed the statistical analyses. $Y Y$ helped synthesize data and gave methodological guidance on the use of RevMan 5.3 and TSA 0.9 Beta software. HBQ provided methodological guidance on drafting and revising the manuscript. All authors read and approved the final manuscript

\section{Acknowledgements}

There was no assistance with the study.

Received: 15 July 2015 Accepted: 6 November 2015 Published online: 01 December 2015

\section{References}

1. Sayre MR, Koster RW, Botha M, Cave DM, Cudnik MT, Handley AJ, et al. Part 5: Adult basic life support: 2010 international consensus on cardiopulmonary resuscitation and emergency cardiovascular care science with treatment recommendations. Circulation. 2010;122:S298-324.

2. Herlitz J, Engdahl J, Svensson L, Angquist KA, Silfverstolpe J, Holmberg S. Major differences in 1-month survival between hospitals in Sweden among initial survivors of out-of-hospital cardiac arrest. Resuscitation. 2006;70:404-9.

3. Langhelle A, Tyvold SS, Lexow K, Hapnes SA, Sunde K, Steen PA. In-hospital factors associated with improved out come after out-of-hospital cardiac arrest. A comparison between four regions in Norway. Resuscitation. 2003;56:247-63.

4. Schneider A, Böttiger BW, Popp E. Cerebral resuscitation after cardiocirculatory arrest. Anesth Analg. 2009:108:971-9.

5. Peberdy MA, Callaway CW, Neumar RW, Geocadin RG, Zimmerman JL, Donnino M, et al. Part 9: post-cardiac arrest care: 2010 American Heart Association guidelines for cardiopulmonary resuscitation and emergency cardiovascular care. Circulation. 2010;122:S768-86.

6. Bernard SA, Gray TW, Buist MD, Jones BM, Silvester W, Gutteridge G, et al. Treatment of comatose survivors of out-of-hospital cardiac arrest with induced hypothermia. N Engl J Med. 2002;346:557-63.

7. Hypothermia after Cardiac Arrest Study Group. Mild therapeutic hypothermia to improve the neurologic outcome after cardiac arrest. N Engl J Med. 2002;346:549-56

8. Coimbra C, Wieloch T. Moderate hypothermia mitigates neuronal damage in the rat brain when initiated several hours following transient cerebral ischemia. Acta Neuropathol. 1994;87:325-31.

9. Sessler DI. Complications and treatment of mild hypothermia. Anesthesiology. 2001;95:531-43.

10. Nielsen N, Friberg H, Gluud C, Herlitz J, Wetterslev J. Hypothermia after cardiac arrest should be further evaluated. A systematic review of randomised trials with meta-analysis and trial sequential analysis. Int J Cardiol. 2011;151:333-41.

11. Nielsen N, Wetterslev J, Cronberg T, Erlinge D, Gasche Y, Hassager C, et al. Targeted temperature management at $33{ }^{\circ} \mathrm{C}$ versus $36{ }^{\circ} \mathrm{C}$ after cardiac arrest. N Engl J Med. 2013;369:2197-206.

12. Arrich J, Holzer M, Havel C, Müllner M, Herkner H. Hypothermia for neuroprotection in adults after cardiopulmonary resuscitation. Cochrane Database Syst Rev. 2012;9, CD004128.

13. Atkins $D$, Best $D$, Briss PA, Eccles $M$, Falck-Ytter $Y$, Flottorp $S$, et al. Grading quality of evidence and strength of recommendations. BMJ. 2004;328:1490

14. Higgins JPT, Green S (editors). Cochrane Handbook for Systematic Reviews of Interventions Version 5.1.0 [updated March 2011]. The Cochrane Collaboration, 2011. Available from www.cochrane-handbook.org.

15. Higgins JP, Thompson SG, Deeks JJ, Altman DG. Measuring inconsistency in meta-analyses. BMJ. 2003;327:557-60.

16. Wetterslev J, Thorlund K, Brok J, Gluud C. Trial sequential analysis may establish when firm evidence is reached in cumulative meta-analysis. J Clin Epidemiol. 2008;61:64-75.

17. Brok J, Thorlund K, Wetterslev J, Gluud C. Apparently conclusive metaanalyses may be inconclusive-trial sequential analysis adjustment of random error risk due to repetitive testing of accumulating data in apparently conclusive neonatal meta-analyses. Int J Epidemiol. 2009;38:287-98. 
18. Thorlund K, Devereaux PJ, Wetterslev J, Guyatt G, loannidis JP, Thabane L, et al. Can trial sequential monitoring boundaries reduce spurious inferences from meta-analyses? Int J Epidemiol. 2009;38:276-86.

19. Wetterslev J, Thorlund K, Brok J, Gluud C. Estimating required information size by quantifying diversity in random-effects model meta-analyses. BMC Med Res Methodol. 2009;9:86.

20. Mori K, Takeyama Y, Itoh Y. Multivariate analysis of prognostic factors in survivors of out-of-hospital cardiac arrest with brain hypothermia therapy. Crit Care Med. 2000;28:A168.

21. Laurent I, Adrie C, Vinsonneau C, Cariou A, Chiche JD, Ohanessian A, et al. High-volume hemofiltration after out-of-hospital cardiac arrest: a randomized study. J Am Coll Cardiol. 2005;46:432-7.

22. Hachimi-Idrissi S, Corne L, Ebinger G, Michotte Y, Huyghens L. Mild hypothermia induced by a helmet device: a clinical feasibility study. Resuscitation. 2001;51:275-81

23. Callaway CW, Donnino MW, Fink EL, Geocadin RG, Golan E, Kern KB, et al. Part 8: Post-Cardiac Arrest Care: 2015 American Heart Association Guidelines Update for Cardiopulmonary Resuscitation and Emergency Cardiovascular Care. Circulation. 2015;132:S465-82.

24. Nielsen N, Sunde K, Hovdenes J, Riker RR, Rubertsson S, Stammet P, et al. Adverse events and their relation to mortality in out-of-hospital cardiac arrest patients treated with therapeutic hypothermia. Crit Care Med. 2011;39:57-64.

25. Dumas F, Grimaldi D, Zuber B, Fichet J, Charpentier J, Pène F, et al. Is hypothermia after cardiac arrest effective in both shockable and nonshockable patients? Insights from a large registry. Circulation. 2011;123:877-86.

26. Janata A, Holzer M. Hypothermia after cardiac arrest. Prog Cardiovasc Dis. 2009;52:168-79.

27. Lopez-de-Sa E, Rey JR, Armada E, Salinas P, Viana-Tejedor A, Espinosa-Garcia $S$, et al. Hypothermia in comatose survivors from out-of-hospital cardiac arrest: pilot trial comparing 2 levels of target temperature. Circulation. 2012;126:2826-33

28. Che D, Li L, Kopil CM, Liu Z, Guo W, Neumar RW. Impact of therapeutic hypothermia onset and duration on survival, neurologic function, and neurodegeneration after cardiac arrest. Crit Care Med. 2011;39:1423-30.

29. Abella BS, Zhao D, Alvarado J, Hamann K, Vanden Hoek TL, Becker LB. Intra-arrest cooling improves outcomes in a murine cardiac arrest model. Circulation. 2004;109:2786-91.

30. Diao M, Huang F, Guan J, Zhang Z, Xiao Y, Shan Y, et al. Prehospital therapeutic hypothermia after cardiac arrest: a systematic review and meta-analysis of randomized controlled trials. Resuscitation. 2013;84:1021-8.

31. Kagawa E, Inoue I, Kawagoe T, Ishihara M, Shimatani Y, Kurisu S, et al. History of diabetes mellitus as a neurologic predictor in comatose survivors of cardiac arrest of cardiac origin treated with mild hypothermia. Resuscitation. 2009;80:881-7.

32. Prior J, Lawhon-Triano M, Fedor D, Vanston VJ, Getts R, Smego Jr RA Community-based application of mild therapeutic hypothermia for survivors of cardiac arrest. South Med J. 2010;103:295-300

33. Uray T, Malzer R. Vienna Hypothermia after Cardiac Arrest (HACA) Study Group. Out-of-hospital surface cooling to induce mild hypothermia in human cardiac arrest: a feasibility trial. Resuscitation. 2008;77:331-8.

34. Xiao G, Guo Q, Shu M, Xie X, Deng J, Zhu Y, et al. Safety profile and outcome of mild therapeutic hypothermia in patients following cardiac arrest: systematic review and meta-analysis. Emerg Med J. 2013;30:91-100.

35. Bro-Jeppesen J, Hassager C, Wanscher M, Søholm H, Thomsen JH, Lippert FK, et al. Post-hypothermia fever is associated with increased mortality after out-of-hospital cardiac arrest. Resuscitation. 2013:84:1734-40.

\section{Submit your next manuscript to BioMed Central and take full advantage of:}

- Convenient online submission

- Thorough peer review

- No space constraints or color figure charges

- Immediate publication on acceptance

- Inclusion in PubMed, CAS, Scopus and Google Scholar

- Research which is freely available for redistribution

Submit your manuscript at www.biomedcentral.com/submit 